mgr Agata Czerska

Biblioteka Uniwersytecka im. Jerzego Giedroycia

a.czerska@uwb.edu.pl

mgr Wiesław Wróbel

Biblioteka Uniwersytecka im. Jerzego Giedroycia

w.wrobel@uwb.edu.pl

\title{
DOŚWIADCZENIA BIBLIOTEKI UNIWERSYTECKIEJ IM. JERZEGO GIEDROYCIA W POZYSKIWANIU FUNDUSZY POZABUDŻETOWYCH
}

\author{
THE EXPERIENCES OF THE JERZY GIEDROYC UNIVERSITY LIBRARY \\ IN ACQUIRING THE NON-BUDGET FUNDS
}

\begin{abstract}
Abstrakt
Celem artykułu jest zaprezentowanie działalności i wynikających z niej doświadczeń Biblioteki Uniwersyteckiej im. Jerzego Giedroycia w zakresie fundarisingu, w głównej mierze opartego na pozyskiwaniu środków pozabudżetowych na realizację przedsięwzięć, które nie mogą być zrealizowane w ramach podstawowej działalności instytucji. Treść artykułu oparto głównie na analizie łącznie 8 wniosków o dofinansowanie z lat 2007-2017, na podstawie których zdołano pozyskać fundusze z Europejskiego Funduszu Rozwoju Regionalnego, Ministerstwa Nauki i Szkolnictwa Wyższego i Ministerstwa Kultury i Dziedzictwa Narodowego. W artykule omówiono treść poszczególnych wniosków, odnotowano cele i rezultaty oraz wskazano wysokość dofinansowania i wkładu własnego. Prezentacji dokonań zwieńczonych sukcesem towarzyszy przedstawienie projektów, które nie uzyskały akceptacji instytucji udzielających dofinansowań wraz z uzasadnieniem ich odrzucenia, a także wnioski realizowane w partnerstwie $\mathrm{z}$ innymi instytucjami. W podsumowaniu autorzy zwracają uwage na istotne znaczenie wieloletnich starań metodami prób i błędów, które dały pracownikom Biblioteki istotną wiedzę oraz doświadczenie w pozyskaniu funduszy i ich rozliczaniu. Wszystko to w sposób wymierny przekłada się na istotny rozwój Biblioteki Uniwersyteckiej im. Jerzego Giedroycia.
\end{abstract}


Słowa kluczowe: dotacje ministerialne, doświadczenia w pozyskiwaniu funduszy, fundraising, Biblioteka Uniwersytecka im. Jerzego Giedroycia.

\begin{abstract}
The main goal of the article is to present the activities and the experience of the Jerzy Giedroyc University Library in fundraising, based mostly on gaining non-budgetary funds on realization of the projects that cannot be done within the main activity of the Library. The article consists of the analysis of the 8 fundraising projects in the period 2007-2017, on the basis of which the Library acquired extrabudget money from European Regional Development Fund, Ministry of Science and Higher Education (activities in dissemination of science) and Ministry of Culture and National Heritage. It presents the contents of each of the projects, their goals and effects as well as the amount of granted money and own contribution. The presentation of the successful projects is accompanied with short description of those, which were not accepted by the funding institutions, along with the summary of the substantiation of their rejection. In a short recapitulation, the authors highlight the importance of the multiannual trial and error method that gave Library workers necessary knowledge on how to gain and settle the fundraising projects. All of this translates directly into a significant development of the Jerzy Giedroyc University Library.
\end{abstract}

Keywords: ministerial subsidies, experiences in acquiring funds, fundraising, Jerzy Giedroyc University Library.

Utworzony w 1997 r. Uniwersytet w Białymstoku (UwB) to jedna z największych i najprężniej rozwijających się uczelni na terenie Polski północno-wschodniej. Obecnie na 9 wydziałach pracuje około 900 pracowników naukowych i kształci się blisko 13 tys. studentów, doktorantów i słuchaczy studiów podyplomowych. Uniwersytet posiada również zagraniczny wydział zlokalizowany w Wilnie. Skala uczelni i mnogość realizowanych w niej zadań stawia przed systemem biblioteczno-informacyjnym trudne zadanie pełnienia ważnej funkcji zaplecza naukowo-dydaktycznego dla pracowników naukowych i studentów. System składa się aktualnie z Biblioteki Uniwersyteckiej oraz 11 bibliotek wydziałowych i instytutowych. Mimo zmieniających się nieustannie warunków pracy, najważniejszą misją Biblioteki pozostaje wciąż tworzenie nowoczesnego centrum informacji i utrzymanie najwyższego poziomu działalności w celu aktywnego wspierania procesów naukowo-badawczych. Jednocześnie Biblioteka Uniwersytecka 
pełni funkcję ogólnodostępnej biblioteki publicznej, służącej zaspokajaniu potrzeb edukacyjnych, informacyjnych i kulturalnych mieszkańców Białegostoku i województwa podlaskiego.

Według stanu na koniec 2016 r., księgozbiór całego systemu liczy blisko $1 \mathrm{mln}$ jednostek inwentarzowych druków zwartych, czasopism i zbiorów specjalnych, z czego 602446 jednostek (61,7\%) stanowi księgozbiór Biblioteki Uniwersyteckiej ${ }^{1}$. Składają się na niego cztery kolekcje: Biblioteka Główna (BG), Kolekcja Humanistyczna (BHU), kolekcja Studium Praktycznej Nauki Języków Obcych (SPNJO) oraz zbiory Centrum Dokumentacji Europejskiej (CDE).

$\mathrm{Na}$ swoją podstawową działalność w ciągu roku akademickiego Biblioteka otrzymuje dofinansowanie z ogólnego budżetu uczelni w wymiarze około $3 \%$ kwoty przeznaczonej na podstawowe koszty utrzymania, w tym płace. Dotacja budżetowa pozostaje od wielu lat na niezmienionym poziomie, choć stale rosnące potrzeby, pojawianie się nowych obszarów działalności oraz wzrost zainteresowania wydawnictwami elektronicznymi powodują, że budżet Biblioteki staje się niewystarczający, aby pokryć wszystkie aspekty funkcjonowania placówki. Wymuszają one częste przesunięcia środków między pozycjami budżetu, niespodziewane zmiany wcześniej zaplanowanych wydatków lub nawet rezygnację bądź odkładanie w czasie wielu ważnych inwestycji. W rezultacie skromny i spetryfikowany budżet utrudnia, a czasem nawet uniemożliwia, właściwą realizację podstawowych zadań biblioteki uczelnianej, pomijając zupełnie jakąkolwiek działalność dodatkową, rozwojową lub badawczą. Jest to podstawowa przyczyna, z powodu której Biblioteka Uniwersytecka już od dekady poszukuje innych źródeł finansowania. Starania te mają różne skutki, część z nich spełza na niczym, inne z kolei uzyskują akceptację $\mathrm{w}$ postaci decyzji przyznającej dotację na realizację konkretnych zadań. Jednak bez względu na wyniki, rezultatem prowadzonej od dłuższego czasu działalności fundarisingowej jest z jednej strony coraz skuteczniejsza realizacja misji Biblioteki, ale także suma doświadczeń, która pozwala na skuteczniejsze ubieganie się o różnego rodzaju dotacje. Daje ona także możliwość dzielenia się wiedzą z innymi Bibliotekami, znajdującymi się w podobnej sytuacji, które poszukują swojej szansy na rozwój w środkach pozabudżetowych.

W latach 2007-2017 Biblioteka Uniwersytecka im. Jerzego Giedroycia jako główny wnioskodawca i lider projektu zrealizowała łącznie 8 zadań

1 Sprawozdanie z działalności systemu biblioteczno-informacyjnego i Biblioteki Uniwersyteckiej za 2016 r. (maszynopis). 
dofinansowanych ze środków zewnętrznych, w dwóch natomiast była istotnym partnerem w pozyskaniu i realizacji zadań. Do tej puli należy dodać także kilka opracowanych wniosków, które nie znalazły akceptacji instytucji finansujących. Ze względu na status prawny Biblioteki, będącej ogólnouczelnianą jednostką organizacyjną podmiotu działającego na rzecz nauki, ma ona ograniczoną pulę źródeł finansowania, dlatego do tej pory skupialiśmy się przede wszystkim na tzw. projektach resortowych, a więc organizowanych przez poszczególne ministerstwa, w mniejszym zaś stopniu na funduszach europejskich. Zestawienie wszystkich zrealizowanych zadań wraz ze wskazaniem wysokości dofinansowania i wkładu własnego przedstawia tabela 1 .

Tabela 1. Realizacja zadań ze wskazaniem wysokości dofinansowania i wkładu własnego (w zl)

\begin{tabular}{|c|c|c|c|}
\hline Lp. & $\begin{array}{l}\text { Nazwa zadania, źródło finansowania } \\
\text { i nr umowy }\end{array}$ & $\begin{array}{l}\text { Dofinan- } \\
\text { sowanie }\end{array}$ & $\begin{array}{l}\text { Wkład } \\
\text { własny }\end{array}$ \\
\hline 1. & $\begin{array}{l}\text { Utworzenie Pracowni Digitalizacji w Bibliotece } \\
\text { Uniwersyteckiej im. J. Giedroycia w Białymstoku } \\
\text { na usługi Podlaskiej Biblioteki Cyfrowej, w ramach } \\
\text { Zintegrowanego Programu Operacyjnego Rozwoju } \\
\text { Regionalnego 2004-2006, priorytet I Rozbudowa } \\
\text { i modernizacja infrastruktury służacej wzmac- } \\
\text { nianiu konkurencyjności regionów, działanie 1.3.: } \\
\text { Regionalna infrastruktura społeczna, współfinan- } \\
\text { sowanego z Europejskiego Funduszu Rozwoju } \\
\text { Regionalnego. } \\
\text { Nr umowy: Z/2.20/I/1.3.1./9/06 }\end{array}$ & 68639 & 28147,65 \\
\hline 2. & $\begin{array}{l}\text { Wprowadzenie ksiegozbioru Kolekcji Humani- } \\
\text { stycznej do katalogu komputerowego Biblioteki } \\
\text { Uniwersyteckiej im. Jerzego Giedroycia w Bia- } \\
\text { łymstoku, w ramach dofinansowania ze środków } \\
\text { Ministerstwa Nauki i Szkolnictwa Wyższego. } \\
\text { Nr umowy DUN 898/P-DUN/2013 }\end{array}$ & 146700 & 16300 \\
\hline 3. & $\begin{array}{l}\text { Poszerzenie zasobów naukowych Biblioteki Uni- } \\
\text { wersyteckiej im. Jerzego Giedroycia w Białymstoku } \\
\text { poprzez rozwój repozytorium instytucjonalnego } \\
\text { Uniwersytetu w Białymstoku, w ramach dofinanso- } \\
\text { wania ze środków Ministerstwa Nauki i Szkolnic- } \\
\text { twa Wyższego. } \\
\text { Nr umowy 677/P-DUN/2014 }\end{array}$ & 36000 & 24355 \\
\hline
\end{tabular}


Doświadczenia Biblioteki Uniwersyteckiej im. Jerzego Giedroycia...

\begin{tabular}{|c|c|c|c|}
\hline Lp. & $\begin{array}{c}\text { Nazwa zadania, źródło finansowania } \\
\text { i nr umowy }\end{array}$ & $\begin{array}{l}\text { Dofinan- } \\
\text { sowanie }\end{array}$ & $\begin{array}{l}\text { Wkład } \\
\text { własny }\end{array}$ \\
\hline 4. & $\begin{array}{l}\text { Wydanie tomu pokonferencyjnego „Bibliotekarz } \\
\text { uwolniony - deregulacja czy degradacja?: IV Ogól- } \\
\text { nopolska Konferencja Naukowa, Białystok, 12-14 } \\
\text { czerwca 2013” (praca zbiorowa pod red. Haliny } \\
\text { Brzezińskiej-Stec i Jolanty Żochowskiej), w ramach } \\
\text { dofinansowania ze środków Ministerstwa Nauki } \\
\text { i Szkolnictwa Wyższego. } \\
\text { Nr umowy 556/P-DUN/2014 }\end{array}$ & 6400 & 4400 \\
\hline 5. & $\begin{array}{l}\text { Uniwersytet w Białymstoku i Biblioteka Uniwer- } \\
\text { sytecka im. Jerzego Giedroycia w Białymstoku, we } \\
\text { współpracy z Prawosławną Diecezją Białostocko- } \\
\text {-Gdańską i Fundacją „Oikonomos”, zrealizowała } \\
\text { projekt: Digitalizacja i konserwacja ksiag z lat } \\
\text { 1865-1902 z prawosławnej parafii św. Mikołaja } \\
\text { Cudotwórcy w Białymstoku, dofinansowany przez } \\
\text { Ministerstwo Kultury i Dziedzictwa Narodowego } \\
\text { oraz Marszałka Województwa Podlaskiego. } \\
\text { Nr umowy: 03492/14/FPK/NIMOZ }\end{array}$ & 35000 & 4293 \\
\hline 6. & $\begin{array}{l}\text { Wprowadzanie do obiegu naukowego ksiegozbioru } \\
\text { Biblioteki Uniwersyteckiej im. Jerzego Giedroycia } \\
\text { poprzez retrospektywne opracowanie zbiorów, } \\
\text { w ramach dofinansowania ze środków } \\
\text { Ministerstwa Nauki i Szkolnictwa Wyższego. } \\
\text { Nr umowy 1193/P-DUN/2015 }\end{array}$ & 175000 & 59100 \\
\hline 7. & $\begin{array}{l}\text { Konserwacja, digitalizacja i udostępnienie online } \\
\text { „Topograficznej karty Królestwa Polskiego” } \\
\text { z zasobu Biblioteki Uniwersyteckiej im. Jerzego } \\
\text { Giedroycia w Białymstoku, w ramach dofinanso- } \\
\text { wania ze środków Ministerstwa Nauki i Szkolnic- } \\
\text { twa Wyższego. } \\
\text { Nr umowy 656/P-DUN/2017 }\end{array}$ & 110800 & 0 \\
\hline 8. & $\begin{array}{l}\text { Wzbogacenie Katalogu Centralnego Biblioteki Uni- } \\
\text { wersyteckiej im. Jerzego Giedroycia w Białymstoku } \\
\text { i Centralnego Katalogu NUKAT o rekordy anali- } \\
\text { tyczne czasopism naukowych wydawanych przez } \\
\text { Uniwersytet w Białymstoku, w ramach dofinanso- } \\
\text { wania ze środków Ministerstwa Nauki } \\
\text { i Szkolnictwa Wyższego. } \\
\text { Nr umowy 656/P-DUN/2017 }\end{array}$ & 129600 & 10000 \\
\hline & Razem & 708139 & 146595,65 \\
\hline
\end{tabular}

Źródło: opracowanie własne. 
Najwcześniej pozyskanymi funduszami zewnętrznymi była dotacja Unii Europejskiej w ramach Zintegrowanego Programu Operacyjnego Rozwoju Regionalnego na lata 2004-2006 (priorytet I Rozbudowa i modernizacja infrastruktury stużącej wzmacnianiu konkurencyjności regionów, działanie 1.3. Regionalna infrastruktura społeczna) i współfinansowanego z Europejskiego Funduszu Rozwoju Regionalnego, przeznaczona na budowę Pracowni Digitalizacji Zbiorów stanowiącej zaplecze techniczne utworzonej w 2007 r. Podlaskiej Biblioteki Cyfrowej. Dofinansowanie działania wyniosło 68639 zł, natomiast wkład własny uczelni 28 147,65 zł. Partnerami Biblioteki Uniwersyteckiej były instytucje współtworzące wówczas Podlaską Bibliotekę Cyfrową: Biblioteka Archidiecezjalnego Wyższego Seminarium Duchownego w Białymstoku, Biblioteka Filii Akademii Muzycznej im. Fryderyka Chopina w Warszawie, Biblioteka Politechniki Białostockiej. Dzięki dofinansowaniu Biblioteka Uniwersytecka zakupiła skanery z oprzyrządowaniem do skanowania mikrofilmów i dokumentów papierowych, oprogramowanie do postprodukcji plików graficznych, zestaw komputerowy oraz aparat cyfrowy. Sprzęt został umieszczony w pracowni o powierzchni 74,38 $\mathrm{m}^{2}$ znajdującej się przy Czytelni Zbiorów Specjalnych, co doprowadziło do jej scalenia z Oddziałem Zbiorów Specjalnych i utworzenia nowej jednostki organizacyjnej w strukturze Biblioteki pod nazwą Pracownia Digitalizacji Zbiorów.

Ze względu na typ biblioteki i jej umiejscowienie w strukturze uczelni wyższej, naturalnym źródłem finansowania dla Biblioteki Uniwersyteckiej stało się Ministerstwo Nauki i Szkolnictwa Wyższego, a w szczególności realizowany od wielu lat program Działalność Upowszechniająca Naukę (DUN). W ramach tego programu Biblioteka zdołała pozyskać dofinansowanie dla 6 różnego typu zadań związanych z działalnością dodatkową. Przy czym ich cele oraz ich zakres rzeczowy determinowały podstawowe założenia DUN. Niezależnie od wyjaśnień pojęcia „działalności upowszechniającej naukę", Ustawa z dnia 30 kwietnia 2010 r. o zasadach finansowania nauki $\mathrm{w}$ art. 25 (w swoim pierwotnym brzmieniu) doprecyzowywała, że: „środki finansowe przeznaczone na finansowanie działalności upowszechniającej naukę przyznaje się bibliotekom naukowym niewchodzącym w skład jednostek naukowych, o których mowa w art. 2 pkt 9 lit. a-c, na: 1 . utrzymanie i poszerzanie zasobów bibliotecznych, 2. działalność wydawniczą, 3. opracowywanie zasobów naukowych bibliotek oraz informacji bibliotecznej”2.

2 Ustawa z dnia 30 kwietnia 2010 r. o zasadach finansowania nauki. Dz.U. 2010, poz. 615 wg tekstu ogłoszonego. 
Natomiast w Ustawie $z$ dnia 15 stycznia 2015 r. o zmianie ustawy o zasadach finansowania nauki oraz niektórych innych ustaw, art. 25 omawianej Ustawy otrzymał następujące brzmienie: „środki finansowe przeznaczone na finansowanie działalności upowszechniającej naukę przyznaje się bibliotekom naukowym niewchodzącym w skład jednostek naukowych, o których mowa w art. 2 pkt 9 lit. a-c, na: 1. utrzymanie unikatowych w skali kraju zasobów bibliotecznych o istotnym znaczeniu dla nauki lub jej dziedzictwa, 2. opracowywanie naukowych zasobów bibliotecznych, 3. udostępnianie zasobów bibliotecznych w formie elektronicznej” ${ }^{3}$. W ciągu pięciu lat doszło więc do znaczącej zmiany w zakresie działań bibliotek jako podmiotów działających na rzecz nauki, które mogły być dofinansowane przez Mnisterstwo Nauki i Szkolnictwa Wyższego (MNiSW) w ramach upowszechniania nauki. W 2010 r. były to głównie zadania z zakresu opracowania, utrzymywania i gromadzenia zasobu, dopuszczano jednak możliwość realizacji działalności wydawniczej. Natomiast po nowelizacji z 2015 r. biblioteki będące częścią podmiotów działających na rzecz nauki mają prawo wyłącznie do wnioskowania o finansowanie zadań związanych z utrzymywaniem zasobów (z zaznaczeniem ich unikatowości i jakości), ich opracowaniem oraz udostępnianiem w wersji cyfrowej.

W związku z tym, że od 2010 r. aktualne są wciąż zadania bibliotek w zakresie opracowania zasobów, Biblioteka Uniwersytecka w latach 2013-2017 pozyskała najwięcej środków na ten cel. Zadania dofinansowane przez MNiSW pozwoliły na dokończenie długotrwałego procesu retrokonwersji oraz na opracowanie tzw. rekordu analitycznego dokumentów niesamoistnych wydawniczo. Wszystkie te działania są związane z jednej strony z koniecznością stałego wzbogacania i rozbudowywania centralnego katalogu systemu biblioteczno-informacyjnego UwB, z drugiej zaś z upowszechnianiem informacji o zasobach tego systemu za pośrednictwem Katalogu Centralnego NUKAT, z którym Biblioteka współpracuje od 2004 r. w trybie biernym, a od 2012 r. w pełnym zakresie (zarówno poprzez pobieranie danych, jak i poprzez wprowadzanie rekordów bibliograficznych i KHW do bazy NUKAT).

W 2013 r. Biblioteka Uniwersytecka po raz pierwszy pozyskała dofinansowanie ze środków na działalność upowszechniającą naukę z przeznaczeniem na realizację projektu Wprowadzenie ksiegozbioru Kolekcji Humanistycznej do katalogu komputerowego Biblioteki Uniwersyteckiej.

3 Ustawa z dnia 15 stycznia 2015 r. o zmianie ustawy o zasadach finansowania nauki oraz niektórych innych ustaw. Dz.U. 2015, poz. 249. 
Głównym celem projektu było wprowadzenie do katalogu centralnego 25 tys. woluminów książek z Kolekcji Humanistycznej. Liczba ta stanowiła 50\% księgozbioru tej Kolekcji, który pozostawał poza katalogiem komputerowym. Oprócz uwidocznienia większej liczby woluminów w katalogu lokalnym, równocześnie wprowadzono 500 nowych rekordów bibliograficznych do Centralnego Katalogu NUKAT. Projekt zrealizowany w latach 2013-2014 był „poligonem doświadczalnym” w zakresie podpisywania umowy z MNiSW, prowadzenia projektu i jego rozliczania. Był on wstępem do kolejnego etapu prac nad retrokonwersją zbiorów, na realizację której w 2014 r. złożono kolejny projekt w ramach DUN (opracowanie kolejnych 15 tys. woluminów książek z Kolekcji Humanistycznej), ale mimo uzyskania pozytywnej akceptacji Zespołu Interdyscyplinarnego ds. działalności upowszechniającej naukę, minister Nauki i Szkolnictwa Wyższego odmówił przyznania środków finansowych na realizację zadania, uzasadniając decyzję brakiem funduszy w budżecie. Sprawa opracowania całego księgozbioru Biblioteki Uniwersyteckiej była cały czas sprawą priorytetową, niezbędną do poprawnego funkcjonowania biblioteki, dlatego nie było najmniejszych wątpliwości w kwestii ponownego wnioskowania o fundusze na dalsze prace przy retrokonwersji.

Kolejne zadanie pod nazwą: Wprowadzenie do obiegu naukowego księgozbioru Biblioteki Uniwersyteckiej poprzez retrospektywne opracowanie zbiorów zostało złożone do MNiSW w marcu 2015 r. Główny cel zadania był analogiczny: wprowadzenie do katalogu centralnego Biblioteki nieopracowanego księgozbioru, tym razem jednak w liczbie 40 tys. woluminów. Prace te były realizowane poprzez skopiowanie rekordu bibliograficznego z Centralnego Katalogu NUKAT, zamianę rekordu własnego na rekord NUKAT oraz dopisanie metadanych dotyczących zasobu oraz przysposobienie książki (wklejenie kodu kreskowego i paska magnetycznego do zabezpieczania zbiorów systemem EM). Jednocześnie do Katalogu Centralnego NUKAT trafiło ponownie 500 nowych rekordów bibliograficznych. Projekt uzyskał akceptację i był realizowany do końca 2016 r.

Pozytywne skutki obu projektów obrazują liczby egzemplarzy dostępnych za pośrednictwem katalogu centralnego w latach 2013-2016. Gdy pod koniec 2013 r. przystępowaliśmy do realizacji zadania, wskaźnik opracowania zbiorów w systemie komputerowym wynosił $81 \%$ dla Biblioteki Głównej (368 $261 \mathrm{nr}$ inw.) i zaledwie 62\% dla Kolekcji Humanistycznej (84 $246 \mathrm{nr}$ inw.). Dziś stan opracowania zbiorów przedstawia się następująco: 97\% w przypadku Biblioteki Głównej (437 079 nr inw.) i 94\% w przypadku Kolekcji Humanistycznej (134 928 nr inw.). Wśród osiągniętych efektów 
z pewnością należy wymienić upowszechnienie zbiorów Biblioteki Uniwersyteckiej za pośrednictwem centralnego katalogu systemu biblioteczno-informacyjnego oraz Centralnego Katalogu NUKAT, ale także wzrost dostępności księgozbioru, co już na etapie realizacji zadania było widoczne w rosnącej liczbie wypożyczeń egzemplarzy wprowadzonych do katalogu.

Rozwój i poszerzanie zasobów naukowych Biblioteki Uniwersyteckiej są możliwe także dzięki repozytorium instytucjonalnemu Uniwersytetu w Białymstoku. Nie ulega dziś wątpliwości, że repozytorium uczelniane jest bardzo ważne przede wszystkim ze względów naukowych. Daje ono bowiem teoretycznie nieograniczoną dostępność do rezultatów prac naukowo-badawczych kadry, usprawnia komunikację naukową oraz zwiększa liczbę cytowań, co ma bezpośredni wpływ na wyższą punktację w rankingach uczelni w kraju i na świecie. Uniwersytet w Białymstoku przystąpił do budowy własnego repozytorium cyfrowego w 2013 r. Rozpoczęło ono swoją działalność na podstawie zarządzenia Rektora Uniwersytetu w Białymstoku z dnia 16 maja 2013 r. Początkowo działało w trybie offline wyłącznie w sieci uczelnianej, a dopiero od stycznia 2014 r. uruchomiono je w otwartym dostępie. Okres ten był wymagany przede wszystkim ze względów technicznych, gdyż infrastruktura sieciowa Biblioteki Uniwersyteckiej nie była wówczas przystosowana do obsługi nowoczesnej platformy naukowej, utrudniając znacząco pracę przy budowie zasobu repozytorium oraz wpływając ujemnie na stabilność platformy. Dlatego też we wrześniu 2013 r. do MNiSW został złożony wniosek o dofinansowanie zadania Poszerzenie zasobów naukowych Biblioteki Uniwersyteckiej im. Jerzego Giedroycia w Białymstoku poprzez rozwój repozytorium instytucjonalnego Uniwersytetu $w$ Białymstoku, który wpisywał się w art. 25 obowiązującej wówczas wersji ustawy z 30 kwietnia 2010 r. Głównym celem całego projektu było stworzenie stabilnej platformy działającej w trybie open access, umożliwiającej powszechny dostęp do wyników prac naukowo-badawczych pracowników naukowych Uniwersytetu w Białymstoku oraz wzbogacenie repozytorium o 900 pełnotekstowych dokumentów w ciągu pierwszego roku jego działania (2014 r.). W ramach zadania dużą część budżetu przeznaczono na zakup nowego serwera do obsługi repozytorium. W wyniku realizacji zadania uruchomiono pełną wersję Repozytorium Uniwersytetu w Białymstoku (RUB) w trybie online, posadowioną na nowoczesnym serwerze, a także przeprowadzono szeroko zakrojone działania promocyjne (uroczyste uruchomienie Repozytorium, opracowano oraz wydano materiały informacyjne i promocyjne, przeprowadzono szkolenia użytkowników). 
Do końca realizacji projektu zasób repozytorium został wzbogacony o blisko 1 tys. nowych dokumentów. Wymiernym rezultatem całego działania jest więc sprawnie działające i stale rozwijane Repozytorium Uniwersytetu w Białymstoku (RUB), obsługiwane przez pracowników Biblioteki Uniwersyteckiej. Według stanu z maja 2017 r. platforma udostępnia blisko 4600 dokumentów, a stronę RUB w 2016 r. odwiedziło 658151 użytkowników.

Upowszechnianie, promowanie, popularyzację osiągnięć naukowych oraz wymianę doświadczeń Biblioteka realizuje także poprzez organizowanie od 2007 r. cyklicznych konferencji o zasięgu ogólnopolskim, poświęconych najistotniejszym problemom bibliotekarstwa, szczególnie bibliotek i bibliotekarzy akademickich. Efektem spotkań stały się materiały pokonferencyjne. W latach 2008-2012 wydano w Wydawnictwie Uniwersyteckim trzy tomy. Pierwszy pt. Kultura organizacyjna $w$ bibliotece, kolejny Marketing wewnętrzny i zarzadzanie zasobami ludzkimi w bibliotece i trzeci Bibliotekarz bez biblioteki, czyli bibliotekarstwo uczestniczace. W 2013 r. odbyła się ogólnopolska konferencja pt. Bibliotekarz uwolniony - deregulacja czy degradacja, której rezultatem był zbiór 23 referatów, stanowiących istotne i aktualne źródło wiedzy na temat bibliotekarzy dyplomowanych oraz zagadnień kształcenia bibliotekarzy w Polsce i poza granicami kraju. Korzystając z uprawnień nadanych w ustawie z 30 kwietnia 2010 r., Biblioteka zdecydowała się także na realizację zadania wydawniczego w postaci druku zbioru materiałów pokonferencyjnych. Uzyskanie dotacji Ministerstwa Nauki i Szkolnictwa Wyższego, chociaż w niewielkiej wysokości (projekt kosztował $10800 \mathrm{zł}$ z z czego środki na naukę wynosiły $6400 \mathrm{zł),} \mathrm{podkreśliło} \mathrm{rangę}$ wydawnictwa oraz potwierdziło zgodność działań Biblioteki z polityką naukową państwa.

W 2015 r., w związku z nowelizacją ustawy z 30 kwietnia 2010 r. oraz wprowadzeniem w życie aktu wykonawczego w postaci rozporządzenia MNiSW z 27 października tego roku', ale także realizowanym w tym czasie dużym projektem retrokonwersji zbiorów, Biblioteka nie ubiegała się o dofinansowanie z zakresu DUN. Dopiero w 2016 r., korzystając ze znowelizowanej ustawy i nowego rozporządzenia, przystąpiliśmy do ponownego przygotowywania wniosków o dofinansowanie planowanych działań. W listopadzie 2016 r., po ponownych przesunięciach terminu związanego $\mathrm{z}$ wprowadzeniem w życie kolejnego rozporządzenia z dnia 8 września

4 Rozporzadzenie Ministra Nauki i Szkolnictwa Wyższego z dnia 27 października 2015 r. $w$ sprawie szczegółowych kryteriów i trybu przyznawania oraz rozliczania środków finansowych na działalność upowszechniająca naukę. Dz.U. 2015, poz. 1862. 
2016 r. w zakresie kryteriów i trybu przyznawania oraz rozliczania środków finansowych na działalność upowszechniającą naukę, do MNiSW trafił nowy wniosek w sprawie dofinansowania dwóch zadań: Wzbogacenie Katalogu Centralnego Biblioteki Uniwersyteckiej im. Jerzego Giedroycia w Białymstoku i Centralnego Katalogu NUKAT o rekordy analityczne czasopism naukowych wydawanych przez Uniwersytet $w$ Bialymstoku (rodzaj zadania: nr 2 - opracowanie naukowych zasobów bibliotecznych) oraz Konserwacja, digitalizacja i udostępnienie online „Topograficznej karty Królestwa Polskiego" z zasobu Biblioteki Uniwersyteckiej im. Jerzego Giedroycia $w$ Białymstoku (rodzaj zadania: nr 1 - utrzymanie unikatowych w skali kraju zasobów bibliotecznych o istotnym znaczeniu dla nauki lub jej dziedzictwa). Wniosek w kwietniu 2017 r. został zaakceptowany. Trwają prace nad realizacją wyżej wymienionych zadań.

Pierwsze z nich zakłada wprowadzenie 9 tys. rekordów analitycznych artykułów czasopism naukowych wydawanych przez Filię Uniwersytetu Warszawskiego, a od 1997 przez Uniwersytet w Białymstoku, do Katalogu Centralnego NUKAT i do katalogu centralnego systemu biblioteczno-informacyjnego Uniwersytetu w Białymstoku. W latach 1968-2016 w oficynie wydawniczej uczelni ukazało się 46 tytułów czasopism, zawierających dorobek badawczy i publikacje pracowników naukowych, doktorantów i studentów uczelni z 48 lat istnienia placówki. Odzwierciedlają one wszystkie kierunki badań i kształcenia realizowanego przez Uniwersytet. Realizacja projektu pozwoli na udostępnienie za pośrednictwem Katalogu Centralnego NUKAT pełnej informacji o ich zawartości, co pośrednio przełoży się na upowszechnianie w większym zakresie dorobku naukowego uczelni. Koszt całego zadania wynosi $129600 \mathrm{zl}$, natomiast kwota pozyskana to $99600 \mathrm{zl}$, a więc dotacja MNiSW pozwoli pokryć 92\% kosztów całego zadania.

Drugie zadanie ma charakter projektu konserwatorsko-digitalizacyjnego i obejmuje trzy główne cele: 1. konserwację zabytkowej mapy Topograficzna karta Królestwa Polskiego wyd. I, złożonej z 60 arkuszy, 2. digitalizację zakonserwowanej mapy we współpracy $\mathrm{z}$ Archiwum Państwowym w Białymstoku (w ramach umowy na wspólne prowadzenie Podlaskiej Biblioteki Cyfrowej) oraz 3. udostępnienie online wersji cyfrowej mapy na platformie Podlaskiej Biblioteki Cyfrowej i specjalnie przygotowanej podstrony na witrynie Biblioteki Uniwersyteckiej. Tym razem skorzysta-

5 Rozporzadzenie Ministra Nauki i Szkolnictwa Wyższego z dnia 8 września 2016 r. w sprawie szczegółowych kryteriów i trybu przyznawania oraz rozliczania środków finansowych na działalność upowszechniająca naukę. Dz.U. 2016, poz. 1514. 
liśmy z faktu, że projekty w ramach DUN mogą być finansowane do 100\% kosztów kwalifikowanych, w związku z tym otrzymaliśmy pełną kwotę w wysokości $110800 \mathrm{zł}$ na realizację tego zadania.

Sukcesy nie byłyby możliwe, gdyby nie porażki i błędy, z których wyciągaliśmy wnioski. Do MNiSW w latach 2013-2016 trafiły także wnioski, które kosztowały nas dużo pracy, ale ostatecznie nie uzyskały pozytywnej decyzji. Działo się tak z różnych powodów, albo ze względu na błędy formalne i merytoryczne, albo z braku środków w budżecie ministerstwa. Do niezakwalifikowanych projektów należy budowa nowoczesnej i jednolitej bazy bibliograficznej publikacji pracowników naukowych Uniwersytetu w Białymstoku w oparciu o system Expertus (niezgodność projektu z wytycznymi Ustawy o finansowaniu nauki), pierwsza wersja projektu Konserwacja, digitalizacja i udostępnienie online "Topograficznej karty Królestwa Polskiego" z zasobu Biblioteki Uniwersyteckiej (błędnie skonstruowany budżet, uznany za niegospodarny), Poszerzenie zasobów cyfrowych Biblioteki Uniwersyteckiej im. Jerzego Giedroycia w Białymstoku poprzez rozbudowęeCzytelni (niezgodność projektu z wytycznymi Ustawy o finansowaniu nauki), wreszcie Digitalizacja i udostępnienie online sprawozdań sytuacyjnych wojewody białostockiego $z$ lat 1933-1939 z zasobu Archiwum Państwowego w Białymstoku (brak środków finansowych w budżecie ministerstwa).

Oprócz możliwości płynących z ustawy z dnia 30 kwietnia $2010 \mathrm{r}$. i dofinansowań pozyskiwanych z Ministerstwa Nauki i Szkolnictwa, Biblioteka Uniwersytecka tylko raz aplikowała o dofinansowanie działań przez Ministerstwo Kultury i Dziedzictwa Narodowego (MKiDN). Pod koniec 2013 r. w regulaminie nowej edycji programu Dziedzictwo kulturowe, priorytet 6. Ochrona i cyfryzacja dziedzictwa kulturowego, pojawił się zapis pozwalający na aplikowanie do programów ministra przez uczelnie wyższe. Biblioteka we współpracy z Centrum Kultury Prawosławnej w Białymstoku oraz Prawosławną Diecezją Białostocko-Gdańską przygotowała projekt Digitalizacja i konserwacja ksiag z lat 1865-1902 z prawosławnej parafi św. Mikołaja Cudotwórcyw Białymstoku, polegający na przeprowadzeniu konserwacji i digitalizacjiksiąg protokołów przedślubnych zarchiwumbiałostockiej parafii prawosławnej św. Mikołaja oraz ich udostępnieniu online na platformie Podlaskiej Biblioteki Cyfrowej. Ministerstwo Kultury i Dziedzictwa Narodowego na początku 2014 r. przyznało zmniejszoną dotację, która mimo wszystko pozwoliła na realizację zadania. Oprócz konserwacji i digitalizacji wspomnianych ksiąg, na potrzeby Pracowni Digitalizacji Zbiorów Biblioteki Uniwersyteckiej został zakupiony aparat fotograficzny z zestawem obiektywów oraz dodatkowe wyposażenie stołu reprograficznego. 
W kolejnych latach program został wstrzymany, a od 2016 r. uruchomiono go ponownie pod nazwą Kultura cyfrowa, przy czym zapisy zawarte $\mathrm{w}$ regulaminie nie pozwalały na wnioskowanie o dofinansowanie zadań realizowanych przez uczelnie wyższe. W związku z tym Biblioteka Uniwersytecka zdecydowała się na ścisłą współpracę z Biblioteką Archidiecezjalnego Wyższego Seminarium Duchownego w Białymstoku (AWSD) (do wnioskowania uprawnione są związki religijne i ich osoby prawne). Wykorzystując doświadczenia pozyskane z realizacji projektu digitalizacji oraz konserwacji z 2014 r., wspólnymi siłami został przygotowany wniosek na konserwację i cyfryzację najstarszych starodruków z zasobu Biblioteki AWSD. Projekt uzyskał akceptację MKiDN, a dotacja pozwoliła na konserwację i cyfryzację jedenastu XVI-wiecznych starodruków, które pod koniec 2016 r. zostały udostępnione online na platformie Podlaskiej Biblioteki Cyfrowej. W 2017 r. obie instytucje kontynuują współpracę: w maju przyznano kolejną dotację na realizację drugiego etapu konserwacji i digitalizacji XVI-wiecznych starodruków z kolekcji Biblioteki AWSD.

Podsumowując, należy stwierdzić, że Biblioteka Uniwersytecka przez ostatnie lata zdobyła duże doświadczenie w działalności fundarisingowej, a przytoczone powyżej przykłady są świadectwem przede wszystkim stałego poszerzania umiejętności opracowywania wniosków i skutecznego zabiegania o dotacje. Był to proces stopniowy, znaczony porażkami i sukcesami, które ostatecznie wpłynęły pozytywnie na poziom umiejętności fundraisingowych kadry biblioteki. Wiemy już jak uniknąć podstawowych błędów, jaką treścią i zakresem rzeczowym zadań zainteresować komitety oceniające oraz w jaki sposób skonstruować budżet oraz etapy działań, aby je z łatwością zrealizować, a potem spokojnie rozliczyć. Z drugiej strony działalność fundraisingowa stanowi wyraz dalekowzrocznej polityki rozwoju biblioteki, gdyż projekty realizowane za pomocą środków zewnętrznych są przede wszystkim nastawione na rozwój, rozbudowę i innowacyjność Biblioteki. Chcemy wychodzić naprzeciw oczekiwaniom studentów i pracowników, rozbudowywać coraz chętniej wykorzystywane własne bazy danych i katalogi, Repozytorium UwB i Podlaską Bibliotekę Cyfrową, zabezpieczać cenne dziedzictwo kulturowe regionu oraz je cyfryzować i udostępniać online. Nasze osiągnięcia i doświadczenia są potwierdzeniem, że fundraising w Bibliotece Uniwersyteckiej im. Jerzego Giedroycia jest rzeczywistością przynoszącą wymierne rezultaty. 


\section{Bibliografia}

1. Rozporządzenie Ministra Nauki i Szkolnictwa Wyższego z dnia 27 października 2015 r. w sprawie szczegółowych kryteriów i trybu przyznawania oraz rozliczania środków finansowych na działalność upowszechniającą naukę. Dz.U. 2015, poz. 1862.

2. Rozporządzenie Ministra Nauki i Szkolnictwa Wyższego z dnia 8 września 2016 r. w sprawie szczegółowych kryteriów i trybu przyznawania oraz rozliczania środków finansowych na działalność upowszechniająca naukę. Dz.U. 2016, poz. 1514.

3. Sprawozdanie z działalności systemu biblioteczno-informacyjnego i Biblioteki Uniwersyteckiej za 2016 r. (maszynopis).

4. Ustawa $z$ dnia 15 stycznia 2015 r. o zmianie ustawy o zasadach finansowania nauki oraz niektórych innych ustaw. Dz.U. 2015, poz. 249.

5. Ustawa $z$ dnia 30 kwietnia 2010 r. o zasadach finansowania nauki. Dz.U. 2010, poz. 615. 